\title{
Method Development and Validation for Estimation of Tinofovir Disoproxil Fumarate in Pharmaceutical Preparation by UV-Spectroscopy and HPLC with Force Degradation Study
}

\author{
Bhushan Ashok Bhairav ${ }^{1 *}$ and Machhindra Jayram Chavan ${ }^{2}$ \\ 'Department of Pharmaceutical Sciences, Mewar University, Chittorgarh - 312901, Rajasthan, \\ India; bbhairav@gmail.com \\ ${ }^{2}$ Amrutvahini College of Pharmacy, Savitribai Phule Pune University, Pune - 422605, Maharashtra, India
}

\begin{abstract}
Tinofovir Disoproxil Fumarate (TDF) is an acyclic nucleotide diester analog of adenosine monophosphate from the antiviral category utilized in the AIDS and hepatitis B treatment. In the present study, two analytical methods, i.e. UV and HPLC were developed for the TDF's estimation in pharmaceutical preparation. In the UV method, the mobile phase used was Methanol and water in 60:40 ratio for estimation of the drug at $260 \mathrm{~nm}$ and an assay of the (TDF) obtained was $99.53 \%$. The method's validation was carried out as per ICH Q2 R1 guidelines in which linearity was detected from 10-50 $\mu \mathrm{g} / \mathrm{ml}$ range with a regression value of 0.999 Percent RSD value of accuracy, precision and robustness were below 2. In the HPLC method estimation of (TDF) was evaluated on Cosmosil C-18 (250 mm×4.6ID, Particle size: $5 \mu$ ) column utilizing Methanol: Water (60:40), $0.9 \mathrm{ml} / \mathrm{min}$ of flow rate, detection wavelength was $260 \mathrm{~nm}$ and the time of retention observed was around 4.63 minutes with the assay value $99.07 \%$. HPLC method was also validated according to ICH guidelines, where linearity was detected in the $10-50 \mu \mathrm{g} / \mathrm{ml}$ of range with the regression coefficient value 0.999 . The $\%$ RSD of precision, accuracy, and robustness was below $2 \%$. The study of forced degradation was also performed by the HPLC method utilizing methanol: water (60:40) at $260 \mathrm{~nm}$. From this study, it can be concluded that the developed methods for estimation of (TDF) drug in pharmaceutical preparation are simple, accurate, precise, and can be utilized in the routine analysis for quantification of the drug in a dosage form.
\end{abstract}

Keywords:Force Degradation Study, HPLC, Tinofovir Disoproxil Fumarate, UV, Validation

\section{Introduction}

Tenofovir Disoproxil Fumarate (TDF) (2E)-but-2enedioic acid; bis(\{[(propan-2-yloxy) carbonyl $]$ oxy $\}$ methyl $)\{[(2 \mathrm{R})-1-(6$-amino-9H-purin-9-yl)propan-2-yl] oxy\} methanephosphonate (Figure 1) is a bis-alkoxy ester prodrug of tenofovir a nucleoside monophosphate (nucleotide) analog belongs to a class of antiretroviral drugsknown as nucleotide analogue Reverse Transcriptase
Inhibitors (nRTIs), used to treat HIV/AIDS and is in clinical preliminaries for treatment of hepatitis $\mathrm{B}$ disease. It's molecular formula is $\mathrm{C} 19 \mathrm{H} 30 \mathrm{~N} 5 \mathrm{O} 10 \mathrm{P}$ and molecular weight is $635.52^{1}$. TDF is less absorbed when administered orally due to the existence of two negative charges among its structure which limits its cellular penetration, its passive diffusion across cellular membranes and intestinal mucosa hindering its availability ${ }^{2}$. Following absorption from the gut, TDF is converted to tenofovir rapidly, which

${ }^{*}$ Author for correspondence 
is metabolized within the cells to active anabolite tenofovir, which is an inhibitor of HIV-1 reverse transcriptase and DNA growing chain is terminated. In a range of cells, along with resting cells, TDF exerts an antiviral effect ${ }^{3}$. The objective of the present work is to develop and validate UV and HPLC methods for estimation of TDF in the pharmaceutical product as per the Q1R2 guidelines of ICH. Further the force degradation study is carried out by HPLC.



Figure 1. Chemical structure of TDF disoproxil fumarate ${ }^{3}$.

TDF is excreted in the urine as an unchanged form, with a significant component of active tubular secretion $^{4}$. Long term utilization of TDF disoproxil is related to nephrotoxicity and bone misfortune. The introduction of nephrotoxicity can show up as Fanconi disorder, intense kidney damage, or decay of Glomerular Filtration Rate (GFR) ${ }^{5}$. TDF interacts with did anosine and HIV-1 protease inhibitors. TDF increases didanosine concentrations and can bring about unfriendly impacts, for example, pancreatitis and neuropathy ${ }^{6}$. TDF associates with HIV-1 protease inhibitors, for example, atazanavir, by diminishing atazanavir concentrations while increasing TDF concentrations ${ }^{7}$. Literature survey revealed that few analytical methods like RP-HPLC, UV, LC-MS, HPTLC have been reported for simultaneous determination of other drugs with TDF disoproxil fumarate in pharmaceutical preparation ${ }^{8-20}$. Hence an effort has been taken in the present study to develop UV and HPLC methods for estimation of (TDF) in pharmaceutical preparation and also the force degradation study of the (TDF) was performed by HPLC method utilizing Cosmosil C-18 $(250 \mathrm{~mm} \times 4$.6ID, Particle size: $5 \mu)$ column and methanol: water (60:40) as mobile phase.

\section{Materials and Methods}

\subsection{Chemicals and Reagents Used}

A pure standard reference TDF was obtained as a gift sample from Dr. Reddy's Lab Ltd. Hyderabad, India. Methanol and water of HPLC grade from Thermo Fisher Scientific and TDF tablets manufactured by Cipla Ltd. were bought from the local marketplace.

\subsection{Instruments}

\subsubsection{HPLC}

HPLC Analysis was executed on HPLC-3000 series (Binary gradient framework, Analytical technologies Ltd.) manufactured by Analytical Technologies Ltd., comprising of a siphon with the loop limit of $20 \mu \mathrm{l}$, UV-Vis (model no. UV2012) detector, waters column (250 mm x $4.6 \mathrm{~mm}, 5 \mu)$.

\subsubsection{UV-Visible Spectrophotometer}

The absorbance was recorded on a UV-Visible spectro photometer (UV-3000-M) manufactured by Analytical Technologies Ltd., with a spectral bandwidth $2 \mathrm{~cm}$ furnished with $1 \mathrm{~mm}$ quartz cell at medium scan speed.

\subsubsection{Weighing Balance and Sonicator}

All the weighing was executed on wensar high accuracy electronic balance PGB 100 and sonication was performed on ultra sonicator WUC-4L manufactured by wensar. The Borosilicate $25 \mu \mathrm{l}$ glass syringe was utilized for testing. Mdi $0.2 \mu \mathrm{m}$ membrane filter paper was utilized.

\subsection{Identification of Drug}

\subsubsection{Melting Point Determination}

The melting point of TDF was estimated by utilizing a capillary strategy on a melting point device ${ }^{21}$.

\subsubsection{FTIR Spectroscopy of Drugs}

Fourier Transform Infrared (FT-IR Alpha Brucker, Germany) was utilized to recognize the characteristic functional group blank reading was taken by Potassium 
Bromate $(\mathrm{KBr})$. The small quantity of the sample was combined with standard at the point of examination from $4000-400 \mathrm{~cm}^{-122}$.

\subsubsection{Solubility Studies}

The solubility investigation of TDF was investigated by utilizing various solvents, like methanol, water, and dichloromethane ${ }^{23}$.

\subsection{Selection and Optimization of UV- Visible Spectrophotometric Method ${ }^{24}$}

\subsubsection{Selection of Mobile Phase}

As per the solubility of the drug in water, methanol and dichloromethane, the different combination of these solvents with different ratios was tried and based on the results obtained, the mobile phase was selected.

\subsubsection{Preparation of Standard Stock Solution}

$10 \mathrm{mg}$ of (TDF) was precisely weighed and shifted into a $10 \mathrm{ml}$ volumetric flask, adda adequate volume of mobile phase till the mark to obtain a standard solution of the strength of $1000 \mu \mathrm{g} / \mathrm{ml}$.

\subsubsection{Preparation of Working Solution}

$1 \mathrm{ml}$ of the solution of the standard was pipette and transferred into a volumetric flask of $10 \mathrm{ml}$ and the mobile phase was added till the mark to make a $100 \mu \mathrm{g} /$ $\mathrm{ml}$ of solution.

\subsubsection{Selection of Detection Wavelength $\left(\lambda_{\max }\right)$}

To acquire a wavelength of maximum absorption $\left(\lambda_{\max }\right)$ of (TDF) the $1 \mathrm{ml}$ working solution was diluted to make $10 \mu \mathrm{g} / \mathrm{ml}$ of the solution by the mobile phase and scanned for the entire UV range (200-400 nm) in UV spectrophotometer on the spectrum mode.

\subsubsection{Establishment of the Calibration Curve}

From the working solution of different aliquots were made by diluting $0.1,0.2,0.3,0.4,0.5 \mathrm{ml}$ of solution till $10 \mathrm{ml}$ in a volumetric flask separately with the mobile phase, to get solutions of strength from $10-50 \mu \mathrm{g} / \mathrm{ml}$ of range. Blank reading was taken with methanol: water $(60: 40)$. The absorbance of the working standard was recorded at 260 $\mathrm{nm}$. The standard calibration curve of drug concentration versus absorbance was plotted.

\subsubsection{Assay of (TDF) Tablet}

The average weight of TDF tablets determined by measuring the weight of 10 tablets independently, Assay of TDF tablet was performed by dissolving $12.01 \mathrm{mg}$ tablet powder which is equal to $10 \mathrm{mg}$ of the standard drug in $10 \mathrm{ml}$ of mobile phase in a volumetric flask to get $1000 \mu \mathrm{g} /$ $\mathrm{ml}$ of solution. To dissolve the tablet contents completely sonication of the solution was done for 10 mins. The solution was sifted through $0.22 \mu$ membrane filter. After chromatographic development peak zone was estimated at $260 \mathrm{~nm}$, and (TDF) present in the sample was evaluated from the region of peak \% Assay was evaluated by utilizing the following equation:



\subsubsection{Validation of $U V$-Visible Spectrophotometric Method ${ }^{25-27}$}

The optimized method was validated according to $\mathrm{ICH}$ Q2A (R1) parameters.

\subsubsection{Accuracy (Recovery Study)}

The method of standard addition was utilized to perform accuracy studies in which top re-analyzed samples and an amount is known of the standard drug was combined and exposed to the method. At three different levels, this study was carried out i.e., $(50 \%, 100 \%$, and $150 \%)$. The recovery studies were executed for each level, then \% recovery and standard deviation was calculated is represented in the Table 1.

\subsubsection{Precision}

Intermediate precision (intra-day and intra day) was achieved by utilizing an investigation of $30 \mu \mathrm{g} / \mathrm{ml}$ of concentration of (TDF) drug on the same day multiple times. Inter day precision of the strategy was checked by rehashing a similar examination on the two distinct days. The estimation of absorbance for the test was communicated regarding \% relative standard deviation (\% RSD). 
Table 1. Composition of sample solution for accuracy by UV method

\begin{tabular}{|c|c|c|c|c|}
\hline Sr. No. & \% Recovery & Concentration of Tablet & The concentration of Standard added & Final Concentration \\
\hline 1. & $50 \%$ & $20 \mathrm{ppm}$ & $10 \mathrm{ppm}$ & $30 \mathrm{ppm}$ \\
\hline 2. & $100 \%$ & $20 \mathrm{ppm}$ & $20 \mathrm{ppm}$ & $40 \mathrm{ppm}$ \\
\hline 3. & $150 \%$ & $20 \mathrm{ppm}$ & $30 \mathrm{ppm}$ & $50 \mathrm{ppm}$ \\
\hline
\end{tabular}

\subsubsection{Linearity}

The sample solution of TDF $(1 \mathrm{mg} / \mathrm{ml})$ was made by dissolving $12.01 \mathrm{mg}$ of tablet powder in $10 \mathrm{ml}$ of a volumetric flask in a sufficient mobile phase to dissolve the tablet content and further volume made upto $10 \mathrm{ml}$ to obtain a final concentration of $1000 \mu \mathrm{g} / \mathrm{ml}$. From the above sample solution $0.1,0.2,0.3,0.4,0.5 \mathrm{ml}$ was pipetted out and moved to $10 \mathrm{ml}$ volumetric flask separately and diluted up to $10 \mathrm{ml}$ with the mobile phase, calibration curve of drug concentration versus absorbance was plotted and regression coefficient was determined from the graph.

\subsubsection{Robustness}

To assess the developed method's strength, some parameters purposely fluctuated. These parameters like stream rate $( \pm 1)$ or wavelength of determination $( \pm 1)$ were varied within the specified range. The robustness of the technique was done at the $30 \mu \mathrm{g} / \mathrm{ml}$ concentration. For the assurance of strategy's robustness, parameters like wavelength were varied in a reasonable range and the quantitative impact of the factor was resolved.

\subsection{Selection and Optimization of Chromatographic Condition (HPLC) $)^{28-30}$}

\subsubsection{Selection and Optimization of Mobile Phase}

After trying different solvents in different ratios, methanol: water gave sharp peaks and good resolution. This mobile phase was made by mixing methanol: water in $60: 40 \mathrm{v} / \mathrm{v}$ ratios the following filtration through a membrane filter of $0.45 \mu$, which was then degassed using an ultra sonicator.

\subsubsection{Selection of Wavelength by $U V$-Vis Spectrophotometric Method}

The standard solution of TDF $(1 \mathrm{mg} / \mathrm{ml})$ was made by dissolving $10 \mathrm{mg}$ of unadulterated TDF standard in 10 $\mathrm{ml}$ of the volumetric flask, to it, $5 \mathrm{ml}$ of the mobile phase was combined and to dissolve the drug completely in the solution, it was sonicated and further volume was made till the mark for acquiring solution strength of $1000 \mu \mathrm{g} /$ $\mathrm{ml}$. From this solution, $0.1 \mathrm{ml}$ was diluted up to $10 \mathrm{ml}$ in a volumetric flask. The working standard solution of $10 \mu \mathrm{g} / \mathrm{ml}$ was scanned for the whole UV range (200-400 $\mathrm{nm}$ ) in a $1 \mathrm{~cm}$ quartz cell with the usage of methanol as diluent. The working standard arrangement of $10 \mu \mathrm{g} / \mathrm{ml}$ was examined for the whole UV go (200-400 nm) in a 1 $\mathrm{cm}$ quartz cell using methanol as a diluents.

\subsubsection{Preparation of Standard Stock Solution}

Accurately weigh $10 \mathrm{mg}$ of TDF of standard reference and transfer it to a $10 \mathrm{ml}$ volumetric flask, to it $5 \mathrm{ml}$ of the mobile phase was combined and sonicated for 10 minutes for the drug to dissolve completely, further volume was made up till the mark with diluent to get solution strength of $1000 \mu \mathrm{g} / \mathrm{ml}$. Working standards were prepared by diluting the standard stock solution.

\subsubsection{Establishment of Calibration Curve by HPLC Method}

From standard stocks $0.1,0.2,0.3,0.4$, and $0.5 \mathrm{ml}$ was diluted till $10 \mathrm{ml}$ in a volumetric flask separately to get $10,20,30,40$ and $50 \mu \mathrm{g} / \mathrm{ml}$ of solutions. Each solution's absorbance was taken at $260 \mathrm{~nm}$ and the assessment of the correlation coefficient was determined individually.

\subsubsection{Assay}

10 tablets were weighed separately to determine the average weight. Weight equivalent to $12.02 \mathrm{mg}$ TDF tablet power (equal to $10 \mathrm{mg}$ of standard TDF) was moved to 10 $\mathrm{ml}$ volumetric flask, to it $5 \mathrm{ml}$ diluent was added, and for dissolving the tablet content the solution was sonicated for $10 \mathrm{~min}$ to and then the volume was made till the mark to make a solution of strength $1000 \mu \mathrm{g} / \mathrm{ml}$. The solution was moved to a falcon tube and centrifuged for 30 minutes; the supernatant was sifted through $0.22 \mu$ membrane filter. After chromatographic advancement peak region 
was estimated at $260 \mathrm{~nm}$ and the amount of drug present in the test sample was estimated from the area under the peak. \% Assay was calculated by the following formula:

$\%$ Assay $=\frac{\text { Concentation of drug in } \mu \mathrm{g} / \mathrm{ml} \mathrm{X} \text { Dilution Factor } \times 100 \times \text { Average weight of the sample }}{\text { Label Chaim } \times \text { Weight of the sampletaken }}$

\subsection{Validation of HPLC Method ${ }^{31-33}$}

According to the International Council on Harmonization (ICH) Q2 (R1) and guidelines, the optimized chromatographic method was validated for specificity, accuracy, linearity, LOD and LOQ, specificity.

\subsubsection{Specificity}

The optimized method's specificity was evaluated by relating the chromatograms of marketed preparation, mobile phase and diluent to detect obstructions of excipients, mobile phase and diluent.

\subsubsection{Accuracy (Recovery)}

For recovery studies, the method of standard addition was utilized for checking the accuracy of optimized methods in which to a pre-analyzed sample, the amount known of the standard drug was combined and exposed to the method. These studies were carried out at different three levels, i.e. (50\%, $100 \%$, and $150 \%)$. The recovery studies were carried out, the \% recovery and standard deviation were calculated. The solutions were set up by technique of standard addition is given in Table 2 .

\subsubsection{Precision}

The analytical technique's precision is the level of agreement between the results of single tests when the method is applied again and again to different samples of a homogeneous sample. The analytical strategy's accuracy is normally reported as the standard deviation or the relative standard deviation. Precision is the proportion to the level of repeatability of an analytical technique under typical activity.

\subsubsection{Repeatability}

The method's repeatability is assessed by examining the same sample solution 6 times and the relative standard deviation is determined.

\subsubsection{Intermediate Precision}

\section{i) Intraday Precision}

The intraday precision is evaluated by testing the sample solution 3 times each on the same day with a time interval of 4 hours, based on the results relative standard deviation was determined.

ii) Inter day Precision

The inter-day precision is evaluated by examining the sample solution 3 times a day for 2 days and the relative standard deviation is determined.

\subsubsection{Linearity}

The method's linearity was evaluated at 5 different concentrations by diluting the standard stock solution to make $10-50 \mu \mathrm{g} / \mathrm{ml}$ of solutions. The linearity graph was plotted with the peak zone of drug v/s drug concentration. The data of linearity are given in table 21.

\subsubsection{Preparation of Standard Solution}

From the stock solution $0.1,0.2,0.3,0.4,0.5 \mathrm{ml}$ was pipette out in $10 \mathrm{ml}$ volumetric flask separately, diluent was combined to make the volume till the mark to get solutions of strength $10,20,30,40,50 \mu \mathrm{g} / \mathrm{ml}$.

\subsubsection{Limit of Detection (LOD) and Limit of Quantitation (LOQ)}

The LOD and LOQ were determined utilizing the following conditions, as stated in ICH rules.

$$
\begin{aligned}
& \mathrm{LOD}=3.3 \times \sigma / \mathrm{S} \\
& \mathrm{LOQ}=10 \times \sigma / \mathrm{S}
\end{aligned}
$$

Where $\sigma$ is the standard deviation of the response and $S$ is the slope of the calibration curve

Table 2. Data for accuracy

\begin{tabular}{|c|c|c|c|c|}
\hline $\begin{array}{c}\text { Sr. } \\
\text { No. }\end{array}$ & $\%$ Recovery & The concentration of drug in Tablet & The concentration of Standard drug added & Final Concentration \\
\hline 1. & $50 \%$ & $20 \mathrm{ppm}$ & $10 \mathrm{ppm}$ & $30 \mathrm{ppm}$ \\
2. & $100 \%$ & $20 \mathrm{ppm}$ & $20 \mathrm{ppm}$ & $40 \mathrm{ppm}$ \\
3. & $150 \%$ & $20 \mathrm{ppm}$ & $30 \mathrm{ppm}$ & $50 \mathrm{ppm}$ \\
\hline
\end{tabular}




\subsubsection{Robustness}

It is the measure of the method's capacity to stay unaffected by little yet intentional variety in strategy parameter and gives a sign of its dependability under typical utilization. The strength of an analytical technique is controlled by the investigation of aliquots from homogenous portions by varying physical parameters that may however are still inside the predetermined parameters of the assay. For instance, change in physical parameters like $\mathrm{pH}$ of the mobile stage and its proportion. Standard and test samples were evaluated in triplicate. The various chromatographic conditions under which standard and sample solution were evaluated are given in Table 3.

Table 3. Parameters varied to check the robustness

\begin{tabular}{|c|c|c|}
\hline Sr. No. & Change in flow rate & Different wavelength \\
\hline 1. & $0.8 \mathrm{ml} / \mathrm{min}$ & $256 \mathrm{~nm}$ \\
\hline 2. & $1.0 \mathrm{ml} / \mathrm{min}$ & $258 \mathrm{~nm}$ \\
\hline 3. & $0.9 \mathrm{ml} / \mathrm{min}$ & $262 \mathrm{~nm}$ \\
\hline
\end{tabular}

\subsubsection{System Suitability Study}

System suitability is a pharmacopoeial prerequisite and is utilized to confirm, regardless of whether the reproducibility of the chromatography system is satisfactory for the investigation to be finished. The tests were executed by gathering information from five replicate infusion of the standard solution.

\subsection{Forced Degradation Studies ${ }^{34-36}$}

Force degradation is the deterioration of medicated substances or its product by exposing it to conditions more severe than accelerated degradation conditions. This investigation shows the chemical conduct of the particles which thus helps in the development of formulation and packaging of the product. Therefore oxidative, hydrolytic, photolytic and heat degradation for (TDF) standard solutions have been investigated.

\subsubsection{Oxidative Degradation}

Pipette $1 \mathrm{ml}$ of standard stocks in a volumetric flask, add $1 \mathrm{ml}$ of $3 \%$ hydrogen peroxide $\left(\mathrm{H}_{2} \mathrm{O}_{2}\right)$, and this solution was kept for 24 hours at room temperature. The resulting solutions were diluted to get a $50 \mu \mathrm{g} / \mathrm{ml}$ solution with methanol: water $(60: 40)$ and $20 \mu$ l was injected in the system and from the recorded chromatogram at $260 \mathrm{~nm}$, oxidative stability of the test sample was determined.

\subsubsection{Acid Degradation}

Pipette $1 \mathrm{ml}$ of the stock solution into a volumetric flask, to its $1 \mathrm{ml}$ of $0.1 \mathrm{~N}$ Hydrochloric Acid was combined and reflexed for 2 hours and 30 minutes at $60^{\circ} \mathrm{C}$. This solution was diluted to acquire $50 \mu \mathrm{g} / \mathrm{ml}$ with methanol:water (60:40) of it $20 \mu \mathrm{l}$ was injected into the system and the chromatogram obtained at $260 \mathrm{~nm}$ was utilized for acid stability evaluation.

\subsubsection{Alkaline Degradation}

To $1 \mathrm{ml}$ of stock solution, $1 \mathrm{ml}$ of $0.1 \mathrm{~N}$ sodium hydroxide was combined and reflexed for 2 hours. $1 \mathrm{ml}$ of $0.1 \mathrm{~N}$ sodium hydroxide with $1 \mathrm{ml}$ stock was reflex for 30 minutes at $60^{\circ} \mathrm{C}$. The subsequent solution was diluted to get a $50 \mu \mathrm{g} / \mathrm{ml}$ solution with methanol:water $(60: 40)$ and $20 \mu \mathrm{l}$ were injected into the system and the alkaline stability evaluation was done by its chromatogram at 260 nm.

\subsubsection{Photolytic Degradation}

The photochemical stability was additionally examined by uncovering the stocks in UV light by keeping the beaker at room temperature for 24 hours in a photostability chamber. The resulting solution was diluted to acquire $50 \mu \mathrm{g} / \mathrm{ml}$ of solution with methanol:water (60:40), of it, $20 \mu \mathrm{l}$ was injected into the system and the chromatogram was recorded at $260 \mathrm{~nm}$ to assess the photolytic stability.

\subsubsection{Thermal Degradation}

The standard Drug solution was kept in an oven $60^{\circ} \mathrm{C}$ for 24 hours then diluted to get $50 \mu \mathrm{g} / \mathrm{ml}$ of solution with methanol:water (60:40) from this $20 \mu \mathrm{l}$ was injected into the system and the thermal stability was determined by chromatogram recorded at $260 \mathrm{~nm}$.

\section{Results and Discussion}

\subsection{Identification of Drug}

\subsubsection{Melting Point Determination}

The slim technique was utilized to decide the melting point by using the thieles tube. The Melting point of (TDF) was seen as $278^{\circ} \mathrm{C}$, while its ideal melting point range is from 277 to $279^{\circ} \mathrm{C}$. 


\subsubsection{FTIR Spectrum}

To identify the functional group of the drug, its FTIR spectrum was recorded. The spectrum showed a strong, broad absorption band extending across the region 2500$3500 \mathrm{~cm}^{-1}$ (Table $4 \&$ Figure 2 ).

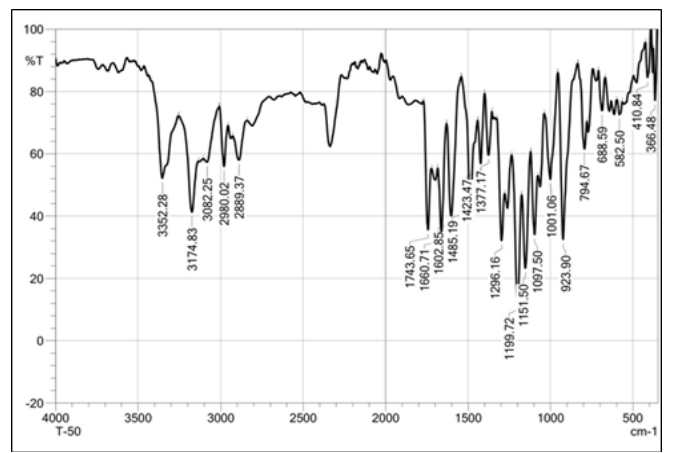

Figure 2. FTIR spectrum of TDF.=

Table 4. IR data of TDF

\begin{tabular}{|c|c|}
\hline Wave number $(\mathrm{cm} 1)$ & Functional group \\
\hline 3352.28 & $\mathrm{~N}-\mathrm{H}$ \\
\hline 3082.25 & Aromatic C-H \\
\hline 2980.02 & Aliphatic C-H \\
\hline 1660.71 & C=C/C=N \\
\hline 1423.47 & Aliphatic C-H \\
\hline 1296.16 & C-O-C \\
\hline $1097.50 / 1001.06$ & C-O-C \\
\hline
\end{tabular}

\subsubsection{Solubility Studies}

Assessment of solubility of the drug was observed in 3 different solvents and it was observed that the drug was slightly soluble in water, very slightly soluble in dichloromethane, and freely soluble in methanol.

\subsection{Development of UV Visible Spectrophotometric Method for TDF}

\subsubsection{Selection and Optimization of Mobile Phase}

Based on the solubility of the drug, methanol and water were selected as the solvents of the mobile phase. Both the solvents were run in different ratios and from the acquired chromatograms it was observed that methanol: water in (60:40) ratio gave good results.

\subsubsection{Selection of Detection of Wavelength}

Solution strength $10 \mu \mathrm{g} / \mathrm{ml}$ of the drug was scanned for the entire UV range, i.e. from 200 to $400 \mathrm{~nm}$, on spectrum mode in UV spectrophotometer. Maximum absorption was observed at $260 \mathrm{~nm}$ (Figure 3).

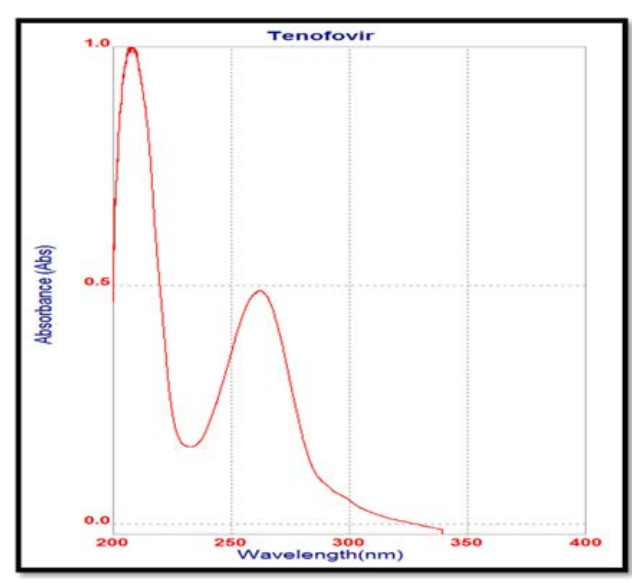

Figure 3. UV spectrum of TDF.

\subsubsection{Establishment of Calibration Curve by UV Method}

The absorbance of each concentration was estimated at the observed analytical wavelength. The standard calibration curves of absorbance versus drug concentration were plotted to utilize the mean of the five different concentrations. The range concentration over which the drug obeyed Beer-Lambert's law was observed between $10-60 \mu \mathrm{g} / \mathrm{ml}$. In the investigation of the calibration curve, a straight line with the regression coefficient 0.999 was obtained that is shown in Figure 4 and Table 5.

Table 5. Data for calibration curve for TDF

\begin{tabular}{|c|c|c|}
\hline Sr. No. & Conc. $(\boldsymbol{\mu g} / \mathbf{m l})$ & Absorbance \\
\hline 1. & 10 & 0.2795 \\
\hline 2. & 20 & 0.4692 \\
\hline 3. & 30 & 0.6594 \\
\hline 4. & 40 & 0.8606 \\
\hline 5. & 50 & 1.0582 \\
\hline
\end{tabular}

\subsubsection{Assay}

Optimized experimental condition for quantification of marketed formulation given as a \% of label claim was acceptable with the label claim, thereby proposing that there is no interference of any excipients. The assay of 


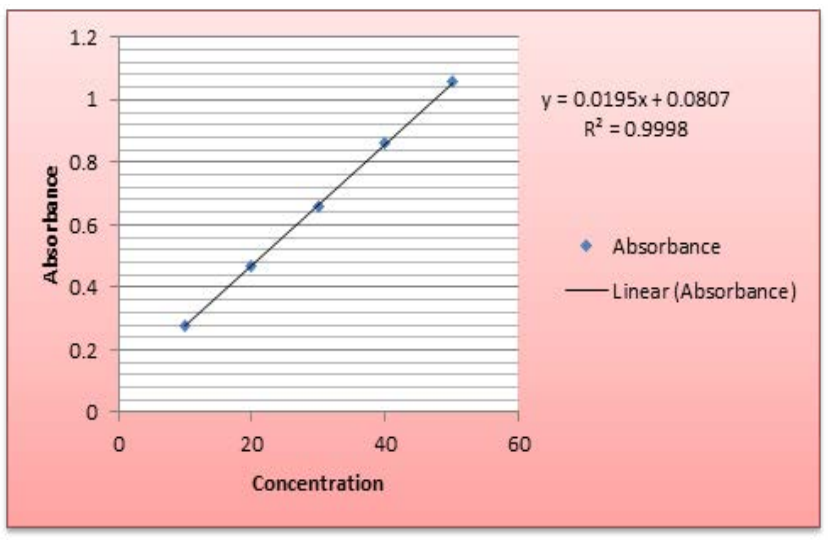

Figure 4. Calibration curve of TDF.

the drug observed was $99.53 \%$ and the standard range of (TDF) is NLT $98.0 \%$ and NMT $102.0 \%$ (Table 6).

Table 6. Assay of TDF

\begin{tabular}{|c|c|c|c|c|c|c|}
\hline $\begin{array}{c}\text { Sr. } \\
\text { No. }\end{array}$ & $\begin{array}{c}\text { Conc. } \\
(\mu \mathrm{g} / \\
\mathrm{ml})\end{array}$ & $\begin{array}{c}\text { Abs. of } \\
\text { sample }\end{array}$ & $\begin{array}{c}\% \\
\text { Assay }\end{array}$ & $\begin{array}{c}\text { Mean } \\
\% \\
\text { Assay }\end{array}$ & S.D. $( \pm)$ & \% RSD \\
\hline 1. & 30 & 0.659 & 99.19 & & & \\
\cline { 1 - 4 } 2. & 30 & 0.6598 & 99.71 & 99.53 & 0.294618 & 0.296009 \\
\cline { 1 - 4 } 3. & 30 & 0.6594 & 99.69 & & & \\
\hline
\end{tabular}

\subsection{Validation of UV Method}

\subsubsection{Accuracy (Recovery Studies)}

The optimized condition was utilized for the estimation of the drug in bulk and pharmaceutical products in the way of spiking extra (TDF), and the \% recovery observed was $99.64 \%$ with $\%$ RSD of $0.56 \%$ (Table $7 \& 8$ ).

\subsubsection{Precision}

Intermediate precision anticipated was performed by utilizing examination of each test solution containing $30 \mu \mathrm{g} / \mathrm{ml}$ in triplicate. The $\%$ RSD was seen at $0.04763 \%$ for intraday precision $0.06578 \%$ for inter-day precision. Therefore, the proposed UV technique was seen to be precise (Table 9\&10).

\subsubsection{Linearity}

For assessing linearity, the calibration graph, i.e. concentration versus absorbance was plotted. It was observed that the optimized method, obey beer- lambert's law as the graph of calibration obtained was linear. The absorbance of each concentration is given in the (Table 11 and Figure 5).

\subsubsection{Robustness}

For the assurance of the technique's robustness, parameter like wavelength was varied within a practical range and the quantitative impact of the factors was resolved. The robustness of the strategy was assessed at a concentration level of $30 \mu \mathrm{g} / \mathrm{ml}$ in triplicate $(\mathrm{n}=3)$ (Table 12).

\subsection{Development of HPLC Method for (TDF)}

\subsubsection{Selection and Optimization of Mobile Phase}

Different mobile phase was run with a different ratio, a sharp peak with minimum tailing was observed with methanol: water in the ratio 60:40. Trial runs on methanol: water is given in (Table 13 and Figure 6\&7).

Table 7. Accuracy determination of (TDF) by UV

\begin{tabular}{|c|c|c|c|c|c|}
\hline Sr. No. & Concentration $(\mu \mathrm{g} / \mathrm{ml})$ & Area & Mean & $\% \mathrm{SD}$ & $\%$ RSD \\
\hline 1. & 10 & 0.2795 & \multirow{3}{*}{0.27943333} & \multirow{3}{*}{0.00020817} & \multirow{3}{*}{0.07449598} \\
\hline 2. & 10 & 0.2792 & & & \\
\hline 3. & 10 & 0.2796 & & & \\
\hline 4. & 30 & 0.6594 & \multirow{3}{*}{0.65943333} & \multirow{3}{*}{0.00035119} & \multirow{3}{*}{0.0532561} \\
\hline 5. & 30 & 0.6598 & & & \\
\hline 6. & 30 & 0.6591 & & & \\
\hline 7. & 50 & 1.0582 & \multirow{3}{*}{1.05846667} & \multirow{3}{*}{0.00030551} & \multirow{3}{*}{0.02886298} \\
\hline 8. & 50 & 1.0588 & & & \\
\hline 9. & 50 & 1.0584 & & & \\
\hline
\end{tabular}


Table 8. Recovery determination of (TDF) by UV

\begin{tabular}{|c|c|c|c|c|}
\hline Sr. No. & Concentration & \% Added & Absorbance & \% Recovery \\
\hline 1. & $20+10$ & $50 \%$ & 0.6589 & 98.99 \\
\hline 2. & $20+20$ & $100 \%$ & 0.8602 & 99.98 \\
\hline 3. & $20+30$ & $150 \%$ & 1.0578 & 99.96 \\
\hline & & Mean & SD & \% RSD \\
\cline { 3 - 5 } & & & \% & 0.56589 \\
\hline
\end{tabular}

Table 9. Intra-day precision for TDF

\begin{tabular}{|c|c|c|c|c|}
\hline $\begin{array}{l}\text { Time } \\
\text { (Day) }\end{array}$ & $\begin{array}{c}\text { Conc. } \\
(\mu \mathrm{g} / \\
\mathrm{ml})\end{array}$ & Absorbance & Mean & $\% \operatorname{RSD}( \pm)$ \\
\hline \multirow{3}{*}{ Morning } & \multirow{3}{*}{30} & 0.6594 & \multirow{6}{*}{0.65943} & \multirow{6}{*}{0.04763} \\
\hline & & 0.6598 & & \\
\hline & & 0.6591 & & \\
\hline \multirow{3}{*}{ Evening } & \multirow{3}{*}{30} & 0.9698 & & \\
\hline & & 0.6591 & & \\
\hline & & 0.6594 & & \\
\hline
\end{tabular}

Table 11. Study of linearity for TDF

\begin{tabular}{|c|c|c|}
\hline Sr. No. & Conc. $(\mu \mathrm{g} / \mathrm{ml})$ & Absorbance \\
\hline 1. & 10 & 0.2795 \\
\hline 2. & 20 & 0.4692 \\
\hline 3. & 30 & 0.6594 \\
\hline 4. & 40 & 0.8606 \\
\hline 5. & 50 & 1.0582 \\
\hline
\end{tabular}

Table10. Inter-day precision for TDF

\begin{tabular}{|c|c|c|c|c|}
\hline $\begin{array}{l}\text { Time } \\
\text { (Day) }\end{array}$ & $\begin{array}{l}\text { Conc. } \\
(\mu \mathrm{g} / \mathrm{ml})\end{array}$ & Absorbance & Mean & $\% \operatorname{RSD}( \pm)$ \\
\hline \multirow{3}{*}{ Day 1} & \multirow{3}{*}{30} & 0.6594 & \multirow{6}{*}{0.65927} & \multirow{6}{*}{0.06578} \\
\hline & & 0.6598 & & \\
\hline & & 0.6591 & & \\
\hline \multirow{3}{*}{ Day 2} & \multirow{3}{*}{30} & 0.6599 & & \\
\hline & & 0.6593 & & \\
\hline & & 0.6597 & & \\
\hline
\end{tabular}

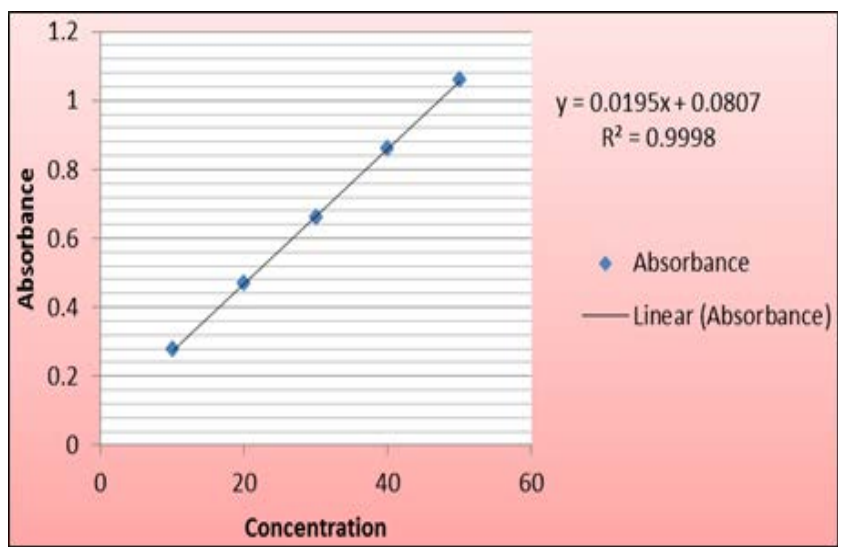

Figure 5. Calibration graph of TDF.

Table 12. Result of robustness at a different wavelength

\begin{tabular}{|c|c|c|c|}
\hline Sr. No. & Concentration & Wavelength & Absorbance \\
\hline 1. & 30 & $264 \mathrm{~nm}$ & 0.6598 \\
\hline 2. & 30 & $265 \mathrm{~nm}$ & 0.6591 \\
\hline 3. & 30 & $263 \mathrm{~nm}$ & 0.6593 \\
\hline & & Mean & 0.6594 \\
\hline & & SD & 0.00036 \\
\hline & & \% RSD & 0.05468 \\
\hline
\end{tabular}


Table 13. Result of optimization of chromatographic conditions

\begin{tabular}{|c|c|c|c|c|c|}
\hline Trial No. & Column used & Mobile phases (v/v) & Retention time & Observation & Results \\
\hline 1. & $\begin{array}{c}\text { CosmosilC18 } \\
(250 \mathrm{~mm} \times 4.6 \mathrm{ID}, \\
\text { Particle size: } 5 \mu)\end{array}$ & Methanol: Water (60:40) & $4.63 \mathrm{~min}$ & $\begin{array}{c}\text { Sharp peak with } \\
\text { minimum tailing }\end{array}$ & Accepted \\
\hline 2. & $\begin{array}{c}\text { CosmosilC18 } \\
(250 \mathrm{~mm} \times 4.6 \mathrm{ID}, \\
\text { Particle size: } 5 \mu)\end{array}$ & Methanol:Water (60:40) & $3.2 \mathrm{~min}$ & Broad peak & Rejected \\
\hline
\end{tabular}

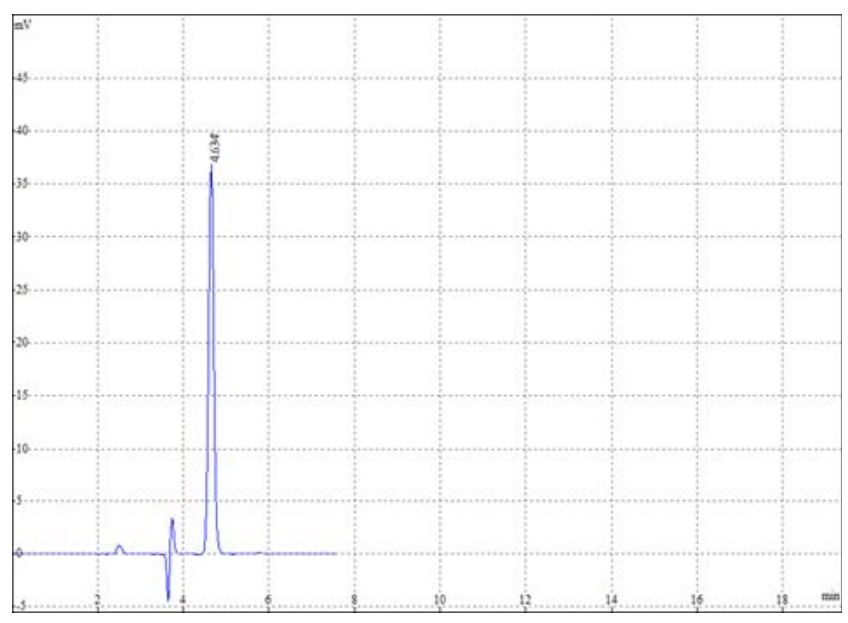

Figure 6. Trial 1-Methanol: Water (60:40) (4.63 minutes of retention time).

\subsubsection{Establishment of Calibration Curve by HPLC Method}

The calibration curve of (TDF) was obtained by plotting a graph of five ascending drug concentrations versus the area of the peak. The regression coefficient acquired was 0.999 with $0.70572 x$ slope (Table 14 and Figure 8 ).

Table 14. Calibration of (TDF) by HPLC method

\begin{tabular}{|c|c|c|}
\hline Sr. No. & Concentration $(\mu \mathrm{g} / \mathrm{ml})$ & Avg. Area \\
\hline 1. & 10 & 314719 \\
\hline 2. & 20 & 879850 \\
\hline 3. & 30 & 1555509 \\
\hline 4. & 40 & 2133827 \\
\hline 5. & 50 & 2785164 \\
\hline
\end{tabular}

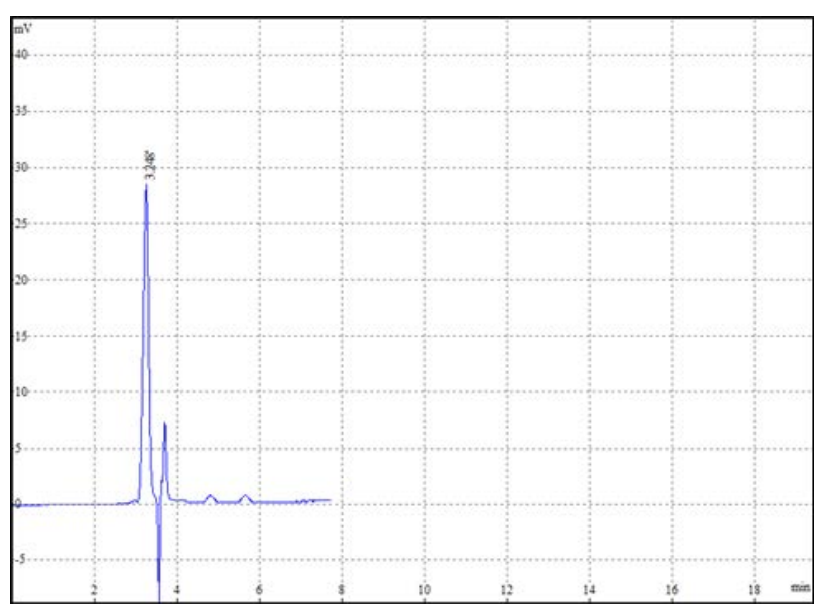

Figure 7. Trial 2-Methanol: Water (60:40) (3.2 minutes of retention time).

\subsubsection{Assay}

The HPLC method developed is sensitive and specific for the quantitative determination of TDF. Tablets of 300 mg strength, manufactured by Cipla were assessed for the content of drug present in the formulation. The assay of the drug was observed to be $99.0716 \%$. The reported



Figure 8. Calibration curve of (TDF). 
standard \% assay range of (TDF) tablets is NLT $90.00 \%$ and NMT $105.0 \%$ of Labeled claim. Chromatograms below represent (TDF) in bulk and tablet dosage form (Table 15 and Figure 9\&10).

Table 15. Assay of (TDF) tablet

\begin{tabular}{|c|c|c|c|c|}
\hline Drug & $\begin{array}{c}\text { The } \\
\text { concentration } \\
\text { of sample } \\
(\mu \mathrm{g} / \mathrm{ml})\end{array}$ & $\begin{array}{c}\text { Area of } \\
\text { standard }\end{array}$ & $\begin{array}{c}\text { Area of } \\
\text { sample }\end{array}$ & \% Assay \\
\hline TDF & 30 & 1574389 & 1559773 & 99.0716 \\
\hline
\end{tabular}

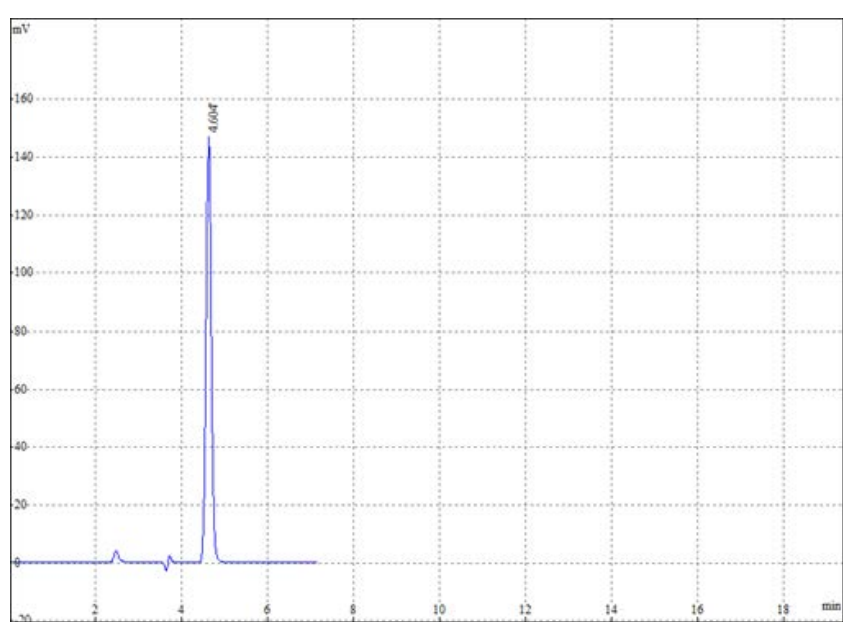

Figure 9. Standard chromatogram of TDF.

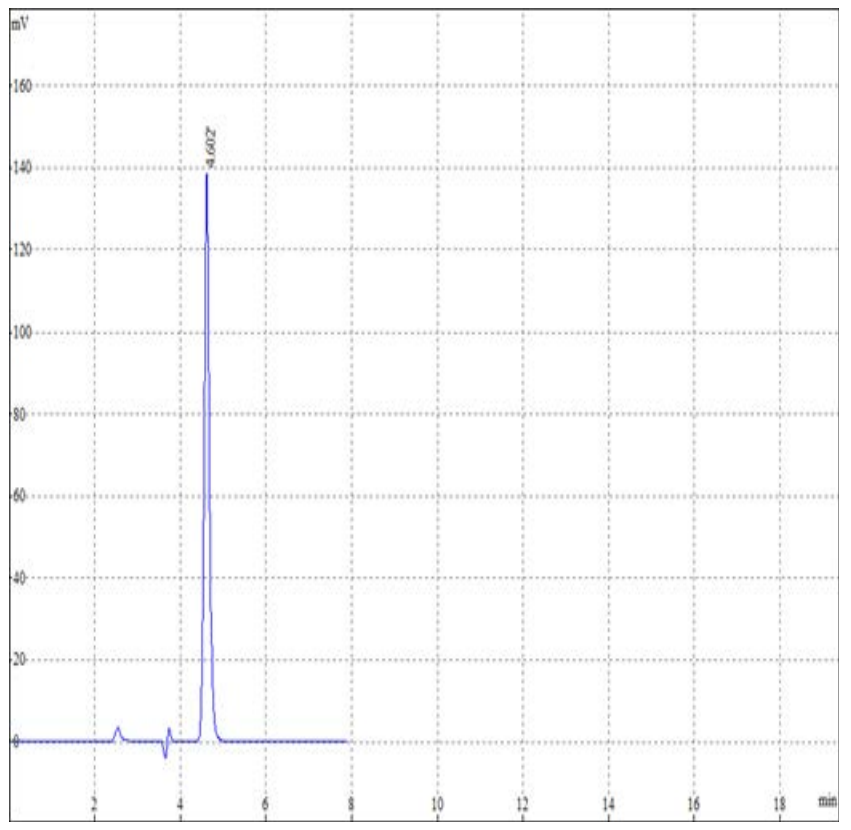

Figure 10. Chromatogram of (TDF) sample.

\subsection{HPLC Method Validation}

\subsubsection{Specificity}

The specificity of the optimized method was observed by injecting only the mobile phase and no peaks of it were observed. Another injection of the sample solution was injected in the system to observe that any interference of excipient with the method, but the only peak observed was of the drug. The chromatograms below represent the specificity of the optimized method (Figure 11\&12).



Figure 11. Chromatogram of mobile phase (Methanol: Water (60:40)).

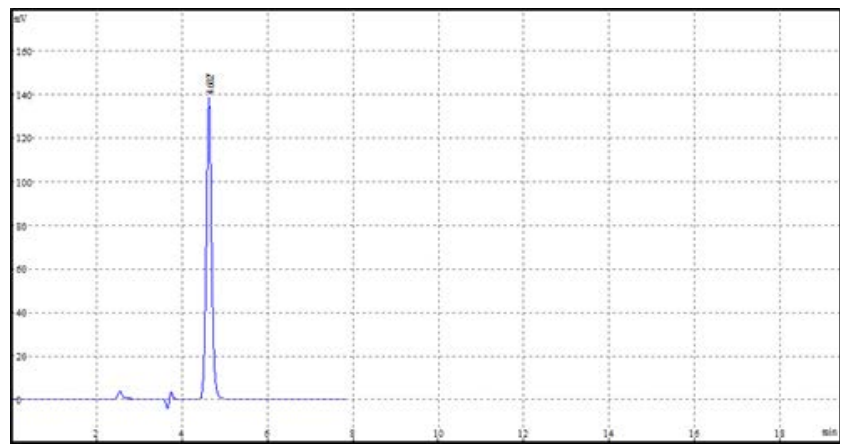

Figure 12. Chromatogram of (TDF) sample for specificity.

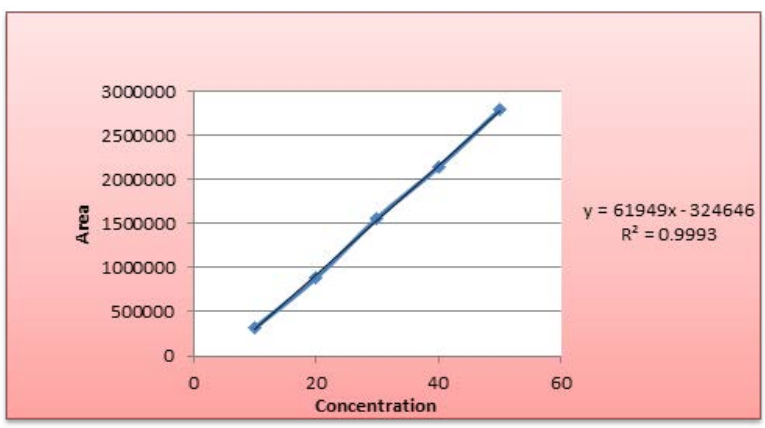

Figure 13. Calibration graph of Tinofovir disproxil fumarate 


\subsubsection{Accuracy (Recovery Studies)}

Three injections per-concentration, i.e. 30, 40, 50 $\mu \mathrm{g} / \mathrm{ml}$ were injected. The amount obtained and the amount added was estimated and the mean recovery of individual recovery values was determined which was within the standard range specified i.e. 90-102\%. Each concentration's relative standard deviation was below 2.0\%.In recovery studies, the optimized method when utilized for the estimation of the drug in pharmaceutical dosage form and bulk, the $\%$ recovery was seen at $99.72 \%$. The data obtained for accuracy and recovery study is given in the (Table $16 \& 17$ ).

\subsubsection{Precision}

Intermediate precision (Intra-day and Inter-day).

The injection standard solution twice in triplicate on the same as well as on 2 consequent days and the peak area was calculated for all injections. The \%RSD for the peak area of triplicate injections was observed to be in the limits specified, i.e. \% RSD of intra-day precision was 0.19 and 0.39 for inter-day precision. The results of intra-day and inter-day precision are summarized in the (Tables 18\&19).

\subsubsection{Linearity}

From the linearity of the calibration graph, it was found that the method optimized obeys Beer-Lamberts law in the range of concentration from $10-50 \mu \mathrm{g} / \mathrm{ml}$ and the regression coefficient obtained from the graph was 0.9993 with slope 61949x and 32464 intercepts. The peak area of all concentration is given in the (Table 20 and Figure 13).

\subsubsection{Limit of Detection and Limit of Quantitation (LOD \& LOQ)}

LOD and LOQ were resolved based on standard deviation acquired from the calibration curve data. LOD for (TDF)

Table 16. Accuracy determination of (TDF) by HPLC

\begin{tabular}{|c|c|c|c|c|c|}
\hline Sr. No. & Concentration $(\mu \mathrm{g} / \mathrm{ml})$ & Area & Mean & $\% \mathrm{SD}$ & $\%$ RSD \\
\hline 1. & 30 & 314719 & \multirow{3}{*}{314824.6667} & \multirow{3}{*}{0.3760955} & \multirow{3}{*}{0.37609} \\
\hline 2. & 30 & 313697 & & & \\
\hline 3. & 30 & 316058 & & & \\
\hline 4. & 40 & 1555509 & \multirow{3}{*}{1557067.667} & \multirow{3}{*}{0.4507214} & \multirow{3}{*}{0.45072} \\
\hline 5. & 40 & 1564734 & & & \\
\hline 6. & 40 & 1550960 & & & \\
\hline 7. & 50 & 2785164 & \multirow{3}{*}{2783311.667} & \multirow{3}{*}{0.3007443} & \multirow{3}{*}{0.3007} \\
\hline 8. & 50 & 2774170 & & & \\
\hline 9. & 50 & 2790601 & & & \\
\hline
\end{tabular}

Table 17. Recovery determination of (TDF) by HPLC

\begin{tabular}{|c|c|c|c|c|}
\hline Sr. No. & \% Recovery level & Area of standard & Area of sample & \% Recovery \\
\hline 1. & $50 \%$ & 1555509 & 1546054 & 99.39216038 \\
\hline 2. & $100 \%$ & 2133827 & 2123852 & 99.53253005 \\
\hline 3. & $150 \%$ & 2785164 & 2791908 & 100.2421401 \\
\hline & & Mean & 99.72227686 \\
\hline & & SD & 0.455652593 \\
\cline { 3 - 5 } & & \% RSD & 0.45692157 \\
\hline
\end{tabular}


Table 18. Intra-day Precision for TDF, $(n=3)$

\begin{tabular}{|c|c|c|c|c|}
\hline Time (Day) & Conc. $(\mu \mathrm{g} / \mathrm{ml})$ & Area & Mean & $\% \operatorname{RSD}( \pm)$ \\
\hline \multirow{3}{*}{ Morning } & \multirow{3}{*}{30} & 1563452 & & \\
\hline & & 1561320 & & \\
\hline & & 1559783 & 1561209 & 0.19 \\
\hline \multirow{3}{*}{ Evening } & \multirow{3}{*}{30} & 1561521 & & \\
\hline & & 1564892 & & \\
\hline & & 1556287 & & \\
\hline
\end{tabular}

Table 19. Inter-day Precision for TDF, $(n=3)$

\begin{tabular}{|c|c|c|c|c|}
\hline Time (Day) & Conc. $(\mu \mathrm{g} / \mathrm{ml})$ & Area & Mean & $\% \operatorname{RSD}( \pm)$ \\
\hline \multirow{3}{*}{ Day 1} & \multirow{3}{*}{30} & 1555509 & \multirow{3}{*}{1554621} & \multirow{3}{*}{0.39} \\
\hline & & 1564734 & & \\
\hline & & 1550960 & & \\
\hline \multirow{3}{*}{ Day 2} & \multirow{3}{*}{30} & 1566466 & & \\
\hline & & 1560250 & & \\
\hline & & 1554621 & & \\
\hline
\end{tabular}

Table 20. Linearity of (TDF) $(n=3)$

\begin{tabular}{|c|c|}
\hline Concentration $(\mu \mathrm{g} / \mathrm{ml})$ & Average Area \\
\hline 10 & 314719 \\
\hline 20 & 879850 \\
\hline 30 & 1555509 \\
\hline 40 & 2133827 \\
\hline 50 & 2785164 \\
\hline
\end{tabular}

obtained was $0.3738 \mu \mathrm{g} / \mathrm{ml}$ while the LOQ was $1.1328 \mu \mathrm{g} /$ $\mathrm{ml}$.

\subsubsection{Robustness}

For the assurance of the technique's robustness, parameters like wavelength and flow rate were changed in a specified range and its impact of the factors was resolved. The technique's strength of the assessed by keeping the constant concentration of $20 \mu \mathrm{g} / \mathrm{ml}$ of (TDF) in triplicate and the $\%$ RSD was detected to be $0.46 \%$ for the flow rate and $0.41 \%$ for the wavelength (Table $21 \& 22$ ).

\subsubsection{System Suitability Study}

System suitability studies demonstrate the proficiency of the column. Several theoretical plates should be more prominent than in 2000 . The estimation of asymmetry factor or following variable must be under 2. Results for system suitability studies of $30 \mu \mathrm{g} / \mathrm{ml}$ solution of the drug
Table 21. Result of robustness for (TDF) at a different flow rate

\begin{tabular}{|c|c|c|c|}
\hline Sr. No. & $\begin{array}{c}\text { Concentration } \\
(\mu \mathrm{g} / \mathrm{ml})\end{array}$ & Flow rate & Area \\
\hline 1. & 20 & $0.8 \mathrm{ml} / \mathrm{min}$ & 873045 \\
\hline 2. & 20 & $1.0 \mathrm{ml} / \mathrm{min}$ & 880443 \\
\hline 3. & 20 & $0.9 \mathrm{ml} / \mathrm{min}$ & 879856 \\
\hline & & Mean & 877781 \\
\cline { 3 - 4 } & & SD & 4112.27 \\
\cline { 3 - 4 } & & \% RSD & 0.468485 \\
\hline
\end{tabular}

Table 22. Result of robustness for (TDF) at a different wavelength

\begin{tabular}{|c|c|c|c|}
\hline Sr. No. & $\begin{array}{c}\text { Concentration } \\
(\mu \mathrm{g} / \mathrm{ml})\end{array}$ & Wavelength & Area \\
\hline 1. & 20 & $258 \mathrm{~nm}$ & 875632 \\
\hline 2. & 20 & $262 \mathrm{~nm}$ & 872584 \\
\hline 3. & 20 & $260 \mathrm{~nm}$ & 879850 \\
\hline & & Mean & 876022 \\
\cline { 3 - 4 } & & SD & 3648.67 \\
\cline { 3 - 4 } & & \% RSD & 0.41650393 \\
\hline
\end{tabular}


obtained were a time of retention - $4.604 \mathrm{~min}$, theoretical plate- 8036 , tailing factor -1.06 , several theoretical plates8036 with a peak zone of 1555509 (Figure 14).



Figure 14. Chromatogram of system suitability of TDF.

\subsection{Degradation Studies}

Forced degradation studies were performed on (TDF) drugs. The respective chromatograms of the degradation study uncover that all the decomposed constituents were evaluated, which shows that the method can be used for degradation evaluation and for observing the TDF's stability in pharmaceutical products and bulk.

\subsubsection{Oxidative Degradation}

The mixture of stock and hydrogen peroxide when injected into the HPLC system to evaluate the drug degraded from the peak zone of sample degraded, the $\%$ degradation calculated was $20.95 \%$. The chromatogram of oxidative degradation is given (Figure 15).

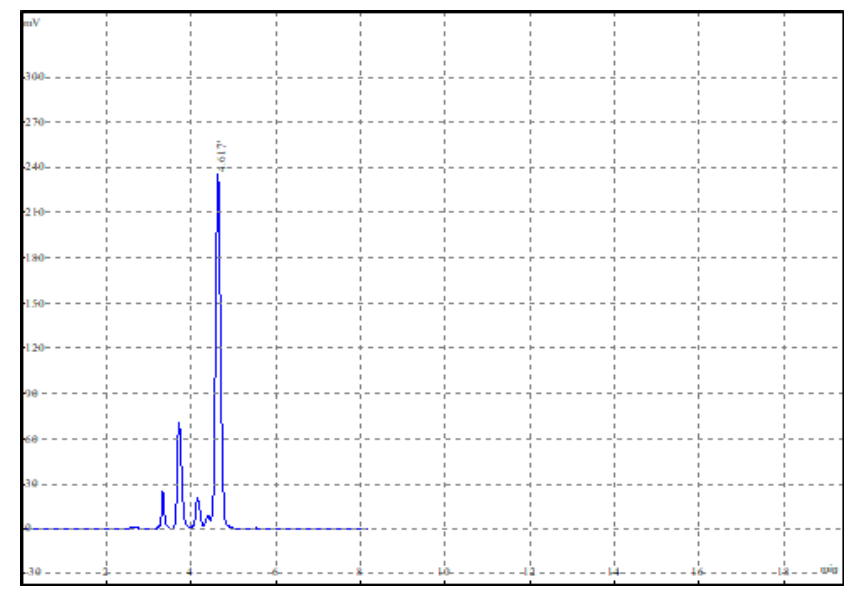

Figure 15. Chromatogram representing oxidative degradation of TDF.

\subsubsection{Acid Degradation}

A solution containing drug and $0.1 \mathrm{NHCl}$ was injected in the system and from the chromatogram obtained it was found that $17.61 \%$ of the drug was degraded due to the presence of acid. The chromatogram of Acid degradation is represented (Figure 16).

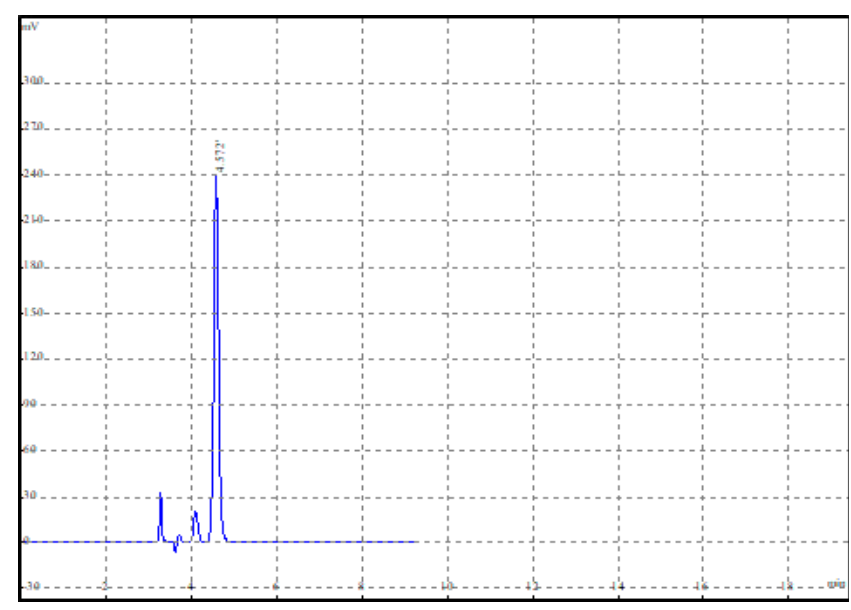

Figure 16. Chromatogram representing acid degradation of TDF.

\subsubsection{Alkaline Degradation}

A solution of drug and $0.1 \mathrm{~N} \mathrm{NaOH}$ was injected in the system for assessing the alkaline degradation. From the chromatograms, it was evaluated that the drug was $15.08 \%$ degraded in the presence of sodium hydroxide. The alkaline degradation chromatogram is given (Figure 17).

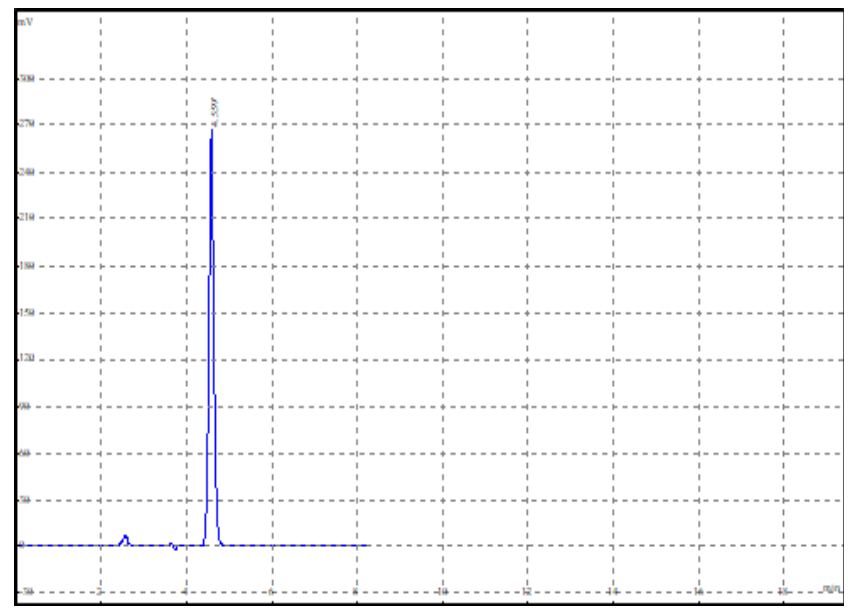

Figure 17. Chromatogram representing alkaline degradation of TDF.

Asian Journal of Pharmaceutical Research and Health Care 


\subsubsection{Photolytic Degradation}

Solution exposed to UV light in a stability chamber for 24 hours was injected in the HPLC system from the chromatogram it was noticed that $0.81 \%$ of the dug was degraded (Figure 18).

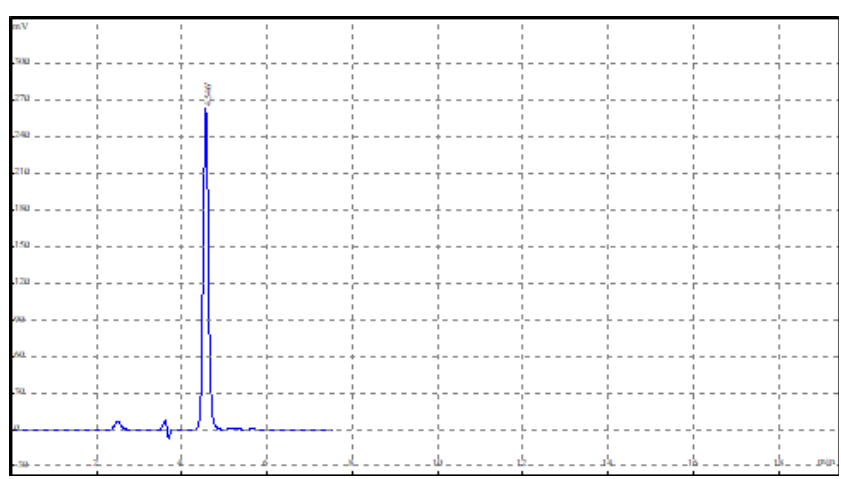

Figure 18. Chromatogram representing photolytic degradation of TDF.

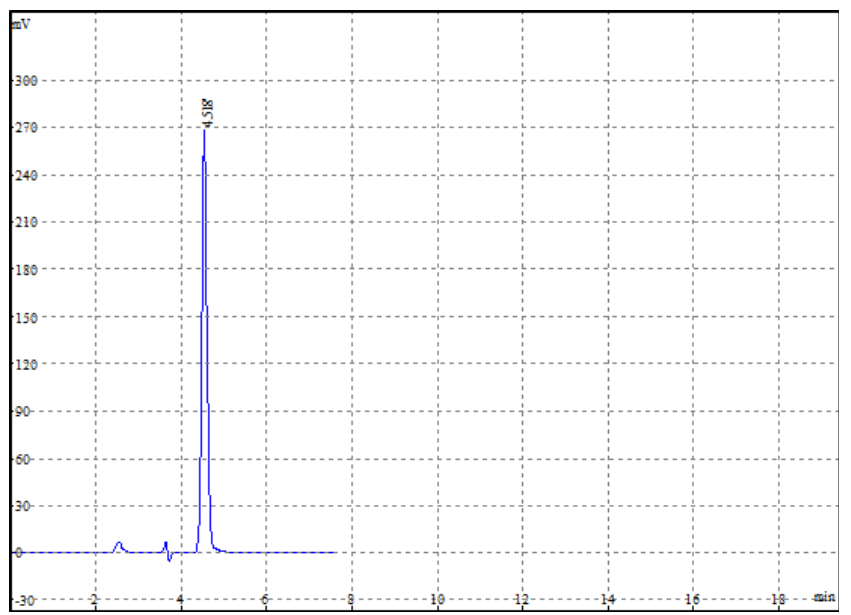

Figure 19. Chromatogram representing thermal degradation of (TDF).

\subsubsection{Thermal Degradation}

To evaluate the degradation due to heat stock solution which was kept in the oven was injected in the system, from the results obtained it was detected that $3.39 \%$ of the drug was degraded when exposed to $60^{\circ} \mathrm{C}$ (Figure 19).

Summarized the force degradation data in (Table 23).

\section{Conclusion}

In the present work UV and HPLC methods for estimation of (TDF) in the pharmaceutical product were
Table 23. Degradation study results of TDF

\begin{tabular}{|c|c|c|c|c|}
\hline $\begin{array}{c}\text { Sr. } \\
\text { No. }\end{array}$ & Condition & $\begin{array}{c}\text { Area of } \\
\text { degraded } \\
\text { sample }\end{array}$ & $\begin{array}{c}\text { Degraded } \\
\text { up to \% }\end{array}$ & $\begin{array}{c}\text { Actual \% } \\
\text { degradation }\end{array}$ \\
\hline 1. & $\begin{array}{c}\text { Oxidative } \\
\text { degradation }\end{array}$ & 2201665 & 79.0497 & 20.9502 \\
\hline 2. & $\begin{array}{c}\text { Acidic } \\
\text { degradation }\end{array}$ & 2294590 & 82.3861 & 17.61382 \\
\hline 3. & $\begin{array}{c}\text { Alkaline } \\
\text { degradation }\end{array}$ & 2364925 & 84.9115 & 15.0884 \\
\hline 4. & $\begin{array}{c}\text { Photolytic } \\
\text { degradation }\end{array}$ & 2762422 & 99.1834 & 0.81654 \\
\hline 5. & $\begin{array}{c}\text { Thermal } \\
\text { degradation }\end{array}$ & 2690683 & 96.6077 & 3.39229 \\
\hline
\end{tabular}

developed and validated as per the guidelines of ICH Q1R2. Methods were developed using methanol:water in 60:40 ratio and detection wavelength determined was $260 \mathrm{~nm}$. The assay value obtained was $99.53 \%$ and 99.07\% of UV and HPLC methods. Linearity was seen in the concentration ranging from $10-50 \mu \mathrm{g} / \mathrm{ml}$ with 0.999 regression coefficient was obtained from UV and HPLC methods. Accuracy, precision and robustness were also evaluated for both the method in which \% RSD obtained was under $2 \%$. Study of force degradation was also performed by the HPLC method utilizing methanol:water (60:40) at $260 \mathrm{~nm}$, in which it was detected that the drug is susceptible to oxidation, photolysis, alkaline, acid and thermal degradation. Hence this method proposed can be employed in routine analysis for quantitative estimation and degradation evaluation of (TDF) in pharmaceutical preparation and bulk.

\section{Conflict of Interest}

Author has no conflict of interest for this research work.

\section{Acknowledgement}

Authors are grateful to the Mewar University, Chittorgarh, Rajasthan, India, for providing facilities to carry out this research work.

\section{References}

1. Delaney WE, Ray AS, Yang H, Qi X, Xiong S, Zhu Y, Miller MD. Intracellular metabolism and in vitro activity of TDF against hepatitis B virus. Antimicrobial Agents 
and Chemotherapy. 2006 Jul 1; 50(7):2471-2477. https:// doi.org/10.1128/AAC.00138-06. PMid: 16801428, PMCid: PMC1489769.

2. Aloy B, Tazi I, Bagnis CI, Gauthier M, Janus N, LaunayVacher V, Deray G, Tourret J. Is TDF alafenamide safer than TDF disoproxil fumarate for the kidneys? AIDS Rev. Oct-Dec 2016; 18(4):184-192. https://pubmed.ncbi.nlm. nih.gov/27438578/. PMID: 27438578.

3. Kearney BP, Flaherty JF, Shah J. TDF disoproxil fumarate. Clinical Pharmacokinetics. 2004 Aug 1; 43(9):595-612. https://doi.org/10.2165/00003088-200443090-00003. PMid: 15217303.

4. Kearney BP, Yale K, Shah J, Zhong L, Flaherty JF. Pharmacokinetics and dosing recommendations of TDF disoproxil fumarate in hepatic or renal impairment. Clinical Pharmacokinetics. 2006 Nov 1; 45(11):11151124. https://doi.org/10.2165/00003088-200645110-00005. PMid: 17048975.

5. Fernandez-Fernandez B, Montoya-Ferrer A, Sanz AB, Sanchez-Nino MD, Izquierdo MC, Poveda J, Sainz-Prestel V, Ortiz-Martin N, Parra-Rodriguez A, Selgas R, Ruiz-Ortega M. TDF nephrotoxicity: 2011 update. AIDS Research and Treatment. 2011. https://doi.org/10.1155/2011/354908. PMid: 21716719, PMCid: PMC3119412.

6. Kearney BP, Sayre JR, Flaherty JF, Chen SS, Kaul S, Cheng AK. Drug-drug and drug-food interactions between TDF disoproxil fumarate and didanosine. The Journal of Clinical Pharmacology. 2005 Dec; 45(12):1360-1367. https://doi. org/10.1177/0091270005281351. PMid: 16291710.

7. Wood R. Atazanavir: Its role in HIV treatment. Expert Review of Anti-Infective Therapy. 2008 Dec 1; 6(6):785796. https://doi.org/10.1586/14787210.6.6.785. PMid: 19053892, PMCid: PMC3805961.

8. Kandagal PB, Manjunatha DH, Seetharamappa J, Kalanur SS. RP-HPLC method for the determination of TDF in pharmaceutical formulations and spiked human plasma. Analytical Letters. 2008 Mar 1; 41(4):561-570. https://doi. org/10.1080/00032710801910742.

9. Sharma R, Mehta K. Simultaneous spectrophotometric estimation of TDF disoproxil fumarate and lamivudine in three component tablet formulation containing efavirenz. Indian Journal of Pharmaceutical Sciences. 2010 Jul; 72(4):527. https://doi.org/10.4103/0250-474X.73926. PMid: 21218073, PMCid: PMC3013570.

10. Bhavsar DS, Patel BN, Patel CN. RP-HPLC method for simultaneous estimation of TDF disoproxil fumarate, lamivudine, and efavirenz in combined tablet dosage form. Pharmaceutical Methods. 2012 Jul 1; 3(2):73-78. https:// doi.org/10.4103/2229-4708.103876. PMid: 23781482, PMCid: PMC3658085.
11. Sentenac S, Fernandez C, Thuillier A, Lechat P, Aymard G. Sensitive determination of TDF in human plasma samples using reversed-phase liquid chromatography. Journal of Chromatography B. 2003 Aug 15; 793(2):317-324. https:// doi.org/10.1016/S1570-0232(03)00333-7.

12. Kandagal PB, Manjunatha DH, Seetharamappa J, Kalanur SS. RP-HPLC method for the determination of TDF in pharmaceutical formulations and spiked human plasma. Analytical Letters. 2008 Mar 1; 41(4):561-570. https://doi. org/10.1080/00032710801910742.

13. Gorja A, Bandla J. Method development and validation for the simultaneous estimation of Lamivudine and TDF disoproxil fumarate in pharmaceutical dosage forms by RP-HPLC. International Journal of Advanced Research in Pharmaceutical and Biomedical Sciences. 2011; 2(1):22-32.

14. Kavitha KY, Geetha G, Hariprasad R, Venkatnarayana R, Subramanian G. Development and validation of RP-HPLC analytical method for simultaneous estimation of Emtricitabine, Rilpivirine, TDF Disoproxil Fumarate and Its pharmaceutical dosage forms. Pharmacie Globale. 2013; 4(1):1.

15. Mali S.A, Salunke P. A, Barhate S.D., Bari M.M. Development and validation of simultaneous RP-HPLC. World Journal of Pharmaceutical Research. 2015; 4(3):995-1006.

16. Nevase PA, Nimje HM, Oswal RJ, Antre RV, Kshirsagar SS. UV spectrophotometric method for estimation of TDF disoproxil fumarate tablet dosage form. Int. J. Pharm. Res. Dev. 2011; 3:73-75. https://doi.org/10.4103/22294708.103876. PMid: 23781482, PMCid: PMC3658085.

17. Gnanarajan G, Gupta AK, Juyal V, Kumar P, Yadav PK, Kailash P. A validated method for development of TDF as API and tablet dosage forms by UV spectroscopy. Journal of Young Pharmacists. 2009 Oct 1; 1(4):351. https://doi. org/10.4103/0975-1483.59326.

18. Anees MI, Baig MS. Determination of lamivudine and TDF in pharmaceutical dosage form by simultaneous and Q-Analysis UV-Spectrophotometric method. WJPPS. 2015; 4(3):688-696.

19. Takahashi M, Kudaka Y, Okumura N, Hirano A, Banno K, Kaneda T. Determination of plasma TDF concentrations using a conventional LC-MS method. Biological and Pharmaceutical Bulletin. 2007 Sep 1; 30(9):1784-1786. https://doi.org/10.1248/bpb.30.1784. PMid: 17827740.

20. Rao J, Gondkar S, Yadav S. Simultaneous HPTLCDensitometric analysis of TDF and Emtricitabine in tablet dosage form. Int. J. Pharm. Tech. Res. 2011; 3(3):1430-1434.

21. Reddy CS, Khan KA, Nagaraja C. A Review on the determination of melting point measurement system. International Journal of Advanced Research in Electrical, Electronics and Instrumentation Engineering. 2016; 5(2):975-979. 
22. Bunaciu AA, Aboul-Enein HY, Fleschin S. Recent applications of fourier transform infrared spectrophotometry in herbal medicine analysis. Applied Spectroscopy Reviews. 2011 Apr 19; 46(4):251-260. https://doi.org/10.1080/0570 4928.2011.565532.

23. Savjani KT, Gajjar AK, Savjani JK. Drug solubility: importance and enhancement techniques. ISRN Pharmaceutics. 2012 Jul 5. https://doi.org/10.5402/2012/195727. PMid: 22830056, PMCid: PMC3399483.

24. Majumder M, Gopinath B, Koni G, Singh SK. New spectrophotometric determination of tinofovir in bulk and pharmaceutical dosage form. Journal of Chemistry. 2009; 6(2):537-540. https://doi.org/10.1155/2009/796402.

25. Ghorpade SA, Sali MS, Kategaonkar AH, Patel DM, Choudhari VP, Kuchekar BS. Simultaneous determination of emtricitabine and TDF by area under curve and dual wavelength spectrophotometric method. Journal of the Chilean Chemical Society. 2010; 55(1):115-117. https://doi. org/10.4067/S0717-97072010000100027.

26. Venkatesan S, Kannappan N. Simultaneous spectrophotometric method for determination of emtricitabine and TDF disoproxil fumarate in three-component tablet formulation containing rilpivirine hydrochloride. International Scholarly Research Notices. 2014. https:// doi.org/10.1155/2014/541727. PMid: 27379309, PMCid: PMC4897216.

27. Nevase PA, Nimje HM, Oswal RJ, Antre RV, Kshirsagar SS. UV Spectrophotometric method for estimation of TDF disoproxil fumarate tablet dosage form. Int. J. Pharm. Res. Dev. 2011; 3:73-75. https://doi.org/10.4103/22294708.103876. PMid: 23781482, PMCid: PMC3658085.

28. Rao J, Gondkar S, Yadav S. Simultaneous HPTLCDensitometric analysis of TDF and emtricitabine in tablet dosage form. Int. J. Pharm. Tech. Res. 2011;3(3):1430-1434.

29. Djerada Z, Feliu C, Tournois C, Vautier D, Binet L, Robinet A, Marty H, Gozalo C, Lamiable D, Millart H. Validation of a fast method for quantitative analysis of elvitegravir, raltegravir, maraviroc, etravirine, TDF, boceprevir and 10 other antiretroviral agents in human plasma samples with a new UPLC-MS/MS technology. Journal of Pharmaceutical and Biomedical Analysis. 2013 Dec 1; 86:100-111. https://doi. org/10.1016/j.jpba.2013.08.002. PMid: 23995753.

30. Pradeep K, Dwivedi SC, Ashok K. Validated HPTLC method for the determination of TDF as bulk drug and in pharmaceutical dosage form. Research Journal of Chemical Sciences. 2011; 2231:606X.

31. Valluru RK, Kumar P, Kilaru NB. High throughput LC-MS/ MS method for simultaneous determination of TDF, lamivudine and nevirapine in human plasma. Journal of Chromatography B. 2013 Jul 15; 931:117-126. https://doi. org/10.1016/j.jchromb.2013.05.008. PMid: 23774246.

32. Devrukhakar PS, Borkar R, Shastri N, Surendranath KV. A validated stability-indicating RP-HPLC method for the simultaneous determination of TDF, emtricitabine, and a efavirenz and statistical approach to determine the effect of variables. ISRN Chromatography. 2013 Jan 28; 2013. https://doi.org/10.1155/2013/878295.

33. Sharma T, Mishra N, Moitra SS, Sankar DG. A validated RP-HPLC method for estimation of TDF disoproxil fumarate in bulk and pharmaceutical formulation. Asian J. Pharm. Clin. Res. 2012; 5(3):108-110.

34. Purnima BV, Reddy TV, Rao YS, Ramu G, Ramachandran D. Stability indicating RP-UPLC method for assay of Emtricitabine and TDF Disoproxil Fumarate in bulk and dosage forms. American Journal of Analytical Chemistry. 2015; 6(10):807. https://doi.org/10.4236/ajac.2015.610077.

35. Hussen SS, Shenoy P, Krishna M. Development and validation of stability indicating RP-HPLC method for TDF nanoparticle formulation. Int. J. Pharm. Pharm. Sci. 2013; 5(2):245-248.

36. Nadig S, Jacob JT, Bhat I, Kishoreraju V. A stability indicating RP-HPLC method for simultaneous estimation of Emtricitabine, TDF disoproxil fumarate and Efavirenz in pharmaceutical dosage forms. International Journal of Research in Pharmaceutical Sciences. 2013 Jul 15; 4(3):391396. 